and destitute of setæ; the thorax much more finely and sparsely punctured, more depressed at the sides in front, much more deeply trisinuate behind, shiny black, and destitute of setæ; the scutellum almost imperceptibly punctured; the elytra more roof-shaped, the striæ more irregular, narrower above than below, filled with shorter and white hair, apical portion filled with long golden-yellow setæ, protruding beyond the abdomen.

The underside is not so densely clothed, and the femora are not so densely punctured and are much more destitute of hair; the tibiæ much more finely punctured, the middle leg with no median spine, and the hind leg with little beyond an excrescence.

This interesting species was presented to the National Collection by Mr. H. Norton, and is one of the most beautiful insects in the genus.

\title{
XXI.-Investigations on new or rare Crustacea of the French
} Coasts. By M. Hesse*.

\section{$\S$ Notopterophorus.}

M. Hesse has obtained individuals of all ages of the curious Crustacean described by him (Ann. Sci. Nat. $5^{\text {e }}$ sér. tome i.) under the name of Notopterophorus papilio, and now gives an account of the life-history of the species.

The male is one-third of the size of the female $(2$ mill. in length), and has the head large and the body short and stout; and the thoracic region, which is of uniform width, does not present an enlargement for the reception of the ova at its base.

The abdominal portion, which is cylindrical, is also shorter and more robust than in the female, and the dorsal membranous expansions are but small at the base, whilst the lobes which accompany them are very long, and gradually diminish to a point. In number and position these expansions are exactly similar to those of the female. The colour is a slightly yellowish white, through which the large intestinal tube, of a yellow colour, with red and black points, may be perceived. The eye is black. The males occur in much smaller numbers than the females, in the interior of Phallusia canina.

In their early states the Notopterophori resemble Cyclops. The body is cylindrical, and formed of four thoracic segments (including the cephalic shield), all of which present posteriorly two triangular acuminate processes; of these the points, directed obliquely, project outwards and on the back, and they are evidently destined to become the membranous expansions of the

* Abstract, by W. S. Dallas, F.L.S. \&c., from Annales des Sciences Naturelles, $5^{\text {e }}$ sér, tom. iii. (1865) pp. 221-242, 
adults. The abdonien, antennæ, and feet exactly resemble those of the adults.

At its first escaping from the egg the body of the young animal is perfectly cylindrical. The antennæ are broad, flat, and rounded at the end ; their joints are not distinctly marked. The first legs are very strong, and composed of four joints, terminated by a stout claw; then follows a pair, thinner, of footjaws, terminated by bristles or spines, and beneath these is the rostrum, formed of two pairs of jaws ; beneath these is another pair of short, slender feet, placed laterally, followed by another larger pair, curved upwards, and furnished with a comb of strong spines or rigid hairs. The thoracic feet are already biramose.

\section{Notopterophorus Bombyx, Hesse.}

This Crustacean, found in the interior of Phallusia intestinalis, is doubtfully described as a new species by the author. The male, as in the preceding species, is one-third of the size of the female. Its head is much larger; the thorax is broad and short, and diminishes gradually in diameter to the abdomen; it is very retractile, the segments forming it have their margins everted so as to favour their invagination, and the lower extremity of the last segment, being capable of vertical elevation, forms a sort of broad, flat surface, which probably serves as a point of support for propulsion.

The membranous dorsal expansions appear to be much less extensive than in $N$. papilio, and that which is implanted upon the nape presents at its base an occipital protuberance. The colour is entirely yellowish white.

The female is elongated, especially in the abdominal region; the head is also very long, and the ridge which forms the base of the occipital membranous expansion is much thicker than in the other species; the membranous expansions are also smaller and thicker. The antennæ and feet are more slender, and the last thoracic segment, which contains the eggs, is remarkable for a peculiar structure which, when seen in profile, presents some analogy with that of Doropygus. The female is very little smaller than that of $N$. papilio; its colour is pale yellow, with a rusty red streak in the middle. The eye is red. The eggs are very dark green, with a transparent limb.

In this species the membranous expansions were more lacerated than in the other. The Crustaceans are seen constantly extending and contracting themselves as if endeavouring to remove something, or to force a passage through resisting objects; their movements of propulsion are aided by the strong claws and spines with which the feet are armed, and the hooks which terminate the abdominal appendages enable them to move back- 
wards. M. Hesse thinks that the membranous expansions may also assist in locomotion; they are moved in the manner of the wings of a butterfly. They are probably employed as a point of support and traction, by being applied hermetically, and by projecting, upon surfaces to which the animals wish to adhere, the lobes by which they are accompanied. There is also a very frequent and active movement of the mandibles, which might lead to the supposition that these parasites are rather masticators than suckers.

The young animal, at the second or third transformation, has a nearly uniformly cylindrical body, diminishing gradually, however, towards the posterior extremity, by which it acquires the appearance of a Cyclops. There is as yet no dorsal appendage ; but the last thoracic segment has commenced the modification which fits it for the reception of the ova. The other appendages, although imperfectly formed, resemble those of the adult. The body is hyaline, with the eye alone red.

\section{Genus Pleurocrypta, gen. nov.}

M. Hesse, in September 1864, discovered under the arch of the branchial cavity of Galatea squamosa a parasitic Crustacean belonging to the group of the Isopoda, which he regards as forming the type of a new genus intermediate between Gyges and Phryxus. He gives the following characters of this parasite, for which he proposes the name of

\section{Pleurocrypta Galatea.}

"Male. Body elongate-ovate, divided into seven nearly equal thoracic segments, of which the first is amalgamated with the head, which is deeply inserted into it; and the last is attached to the abdomen, which is triangular and of a single piece. Feet terminated by a strong hooked and denticulated claw.

"Female. Body ovate, symmetrical, provided above with very long incubatory laminæ, which entirely cover the thoracic portion; abdomen divided into six [five ?] segments, furnished with simple acuminate branchiæ of unequal size; feet terminated by an oblique, ampulliform joint, having a prehensile orifice.

"Length of the male 0.001 , of the female $0.007 \mathrm{~m}$."

The head of the male is amalgamated with the first thoracic segment, forming a sort of buckler, rounded in front and hemispherical above; the six following thoracic segments are of nearly equal width, but the sixth is a little narrower and soldered to the abdomen. The latter is of an elongate triangular form, rounded at the extremity, and presents no trace of segments, unless it be that the lateral margins are slightly undulated. On each side 
of the body, in each segment except the first, the white branching reproductive organs are seen shining through the skin.

On the lower surface of the body the foremost organs are two pairs of short antennæ placed obliquely on the sides of the head, and scarcely passing its margin. The superior antenna is shorter than the other, and of three joints; the inferior antenna has four. The antennæ of each side spring from a common flat basilar piece.

The buccal apparatus is of a somewhat conical form, with the apex, bearing the buccal orifice, directed forward. The organs of the mouth consist of two pairs of hard corneous denticulated jaws, forming a sort of curved nippers, of four other small footjaws, each consisting of three joints and terminated by a crooked claw, and of two flat pointed laminæ forming a lower lip. The thoracic legs consist of five joints, of which the femoral and the apical are the largest; the latter is terminated by a powerful, curved, and denticulated claw, which, by folding down upon a protuberance of the lower surface of the inflated apical joint, becomes a prehensile organ. The body is of a buff colour, with the abdomen reddish brown. The intestinal canal is brick-red, with a fine white line upon it, indicating the course of the interganglionic cord. The surface is covered with short, rigid, and scattered hairs.

The female is much larger than the male, measuring 7 mill. in length by 3 mill. in breadth; its form is a regular oval. The head is hemispherical, and embraced by the first pair of incubatory plates, of which there are in all four pairs, increasing in dimensions as they descend towards the abdomen. The last two plates are longer than the others, and their posterior margin is turned down almost perpendicularly upon the base of the abdomen so as to close the incubatory chamber. At their base these plates present small niche-like cavities for the reception of the feet.

The epimeric pieces are alternately large and small, so as to facilitate the movements of the thorax; from the fifth onward, they become more and more pointed to the extremity of the abdomen. Each of the five segments of the abdomen is provided on each side with a branchial lamina, which is very delicate and contractile; these laminæ, like the segments to which they are attached, diminish in size posteriorly.

The ventral surface is nearly flat, or very slightly concave. The buccal apparatus is placed close to the membranous anterior margin of the head; the orifice is pierced in the middle of a large lip, and from it issue two pointed denticulated jaws, forming a pair of pincers. A little above this orifice are situated the antennæ, which, as in the male, are four in number; the 
superior antennæ are shortest, and composed of three joints; the inferior have a large basal joint, and are terminated by a cylindrical filament of five joints. The eyes are situated on small rounded protuberances close to the base of the inferior antennæ.

The body is divided into twelve segments, seven thoracic and five abdominal ; and, from the arrangement of the former, the animal is enabled to roll itself up into a ball like the woodlice. Each thoracic segment is furnished with a pair of feet, which are articulated laterally to the epimeric pieces at the base of the incubatory laminæ; each foot is formed of five nearly equal joints, and curved in such a manner that its extremity is directed towards the ventral surface. The apical joint, which is larger than the others, is inflated above and flat beneath, and on the first two pairs of feet forms a sort of elastic pad; the apical joints of the other feet are hollow internally and nar rowed at the apex, where there is a small contractile aperture with a raised margin. The anterior half-circumference of this aperture appears to be of a more solid substance, and, furnished with denticulations, may render the organ more efficient in fixation.

The head, abdomen, and whole lower surface of the female are bright yellow, with the two small lateral protuberances of the head reddish brown; the incubatory plates are light vinous grey, and the branchial laminæ transparent and bright blue. Beneath, the segments and epimeric pieces are bounded by white lines.

The young, on escaping from the egg, are minute and very active, swimming rapidly by jerks. The head is hemispherical, rounded in front, and as wide as the first thoracic segment in which it is immersed; this is followed by seven other segments, all of the same size, except the last, which has a small rounded process in the middle. The eyes, situated on the sides of the head, are large and hemispherical; the abdomen is formed of a single piece, as in the male.

The mouth, which is proboscidiform and retractile, is placed at the lower extremity of an oval protuberance, which projects in the middle of the first thoracic segment. The superior antennæ are short, stout, and formed of three joints, the last of which is slender and cylindrical, and truncated at the extremity, and the second bears some strong pointed setæ. The inferior antennæ are much elongated, and composed of five nearly cylindrical joints, which diminish in thickness from the second to the apex.

The legs, as in the adult, are seven on each side, and all formed of five joints, of which the last is the most developed. 
The first pair, as in the male, is terminated by a powerful claw; the last joint of the others is hollow, and terminated by a round orifice.

The abdomen has on each side a broad, lamellar, bifurcate false leg, and these appendages are preceded by others which are also lamellar, pointed and denticulated on the margins; these are organs of propulsion, and subsequently form the branchiæ. In some individuals the extremity of the abdomen bears, close to the anus, two small, flat, rounded, margined laminæ. The body of the young animal is of a pale violet-grey colour, as are also the eggs; and it is to the latter, seen through the transparent incubatory laminæ, that the suprathoracic pouch of the female owes its peculiar tint.

The females of these Crustaceans reside in tumours produced by them on the inner surface of the arch of the branchial cavity in Galatea squamosa; and the males are found adhering to the abdomen of the females, frequently to the branchial laminæ. In many cases two males are attached to one female.

XXII.-Contributions to an Insect Fauna of the Amazons Valley. Coleoptera : Longicornes. By H. W. Bates, Esq.

[Continued from p. 113.]

\section{Hypselomus paganus, Pascoe.}

H. sordide fuscus, nigro obscure irroratus; thorace dorso tuberoso, lateribus tuberculo acuto ; elytris humeris subconicis, antice curvato angulatis, cristis centrobasalibus prominulis, obtusis. Long. 7-8 lin. 0 o 9 .

Head dingy brown. Antennæ blackish brown, bases of the joints (from the fourth) pallid. Thorax with prominent dorsal ridge and, on each side, two well-marked tubercles, sides each with a small acute tubercle; colour dingy tawny brown, speckled with dusky. Elytra with projecting shoulders, the projection somewhat conical, but anterior slope curved or angulated, the apex formed by a thick black tubercle; centro-basal ridges pronounced, but not crested with tubercles; surface dingy tawny brown, speckled or irregularly marked with dusky. Body beneath dingy brown; abdomen black in the middle. Legs blackish, speckled with tawny; base of claw-joint reddish: posterior tibiæ in the male dilated at apex. Supplementary antennal joint of male wanting.

Ega and S. Paulo, Upper Amazons.

\section{Hypselomus seniculus, n. sp.}

H. parvus, fuscus griseo vestitus, summa fronte acute bituberculata; 


\section{$2 \mathrm{BHL}$ Biodiversity Heritage Library}

Hesse, M. 1865. "XXI.-Investigations on new or rare Crustacea of the French Coasts." The Annals and magazine of natural history; zoology, botany, and geology 16, 162-167.

View This Item Online: https://www.biodiversitylibrary.org/item/72304

Permalink: https://www.biodiversitylibrary.org/partpdf/61404

\section{Holding Institution}

University of Toronto - Gerstein Science Information Centre

\section{Sponsored by}

University of Toronto

\section{Copyright \& Reuse}

Copyright Status: NOT_IN_COPYRIGHT

This document was created from content at the Biodiversity Heritage Library, the world's largest open access digital library for biodiversity literature and archives. Visit BHL at https://www.biodiversitylibrary.org. 